\title{
INTERAKSI SOSIAL ANAK DOWN SYNDROME DENGAN LINGKUNGAN SOSIAL (STUDI KASUS ANAK DOWN SYNDOME YANG BERSEKOLAH DI SLB PUSPPA SURYAKANTI BANDUNG)
}

\author{
OLEH: \\ RENAWATI $^{1}$, RUDI SAPRUDIN DARWIS ${ }^{2}$, HERY WIBOWO ${ }^{3}$ \\ 1Mahasiswa Program Studi Kesejahteraan Sosial (170310140019), Fakultas Ilmu Sosial dan Ilmu Politik, Universitas \\ Padjadajaran \\ 2PPusat Studi Kewirausahaan Sosial, CSR, dan Pengembangan Masyarakat, Fakultas Ilmu Sosial dan Ilmu Politik, \\ Universitas Padjadajaran \\ 3PPusat Studi Kesejahteraan Anak dan Keluarga, Fakultas Ilmu Sosial dan Ilmu Politik, Universitas Padjadajaran \\ Email: \\ (renawati21@gmail.com¹, rsdarwis@gmail.com², hery_fortune@yahoo.com³)
}

\begin{abstract}
ABSTRAK
Jumlah penyandang down syndrome di Indonesia ada sekitar 300 ribu lebih. Down syndrome adalah suatu kelainan genetik yang terjadi pada manusia yang menyebabkan mereka yang mengidapnya memiliki kelainan baik fisik maupun psikis. Dalam kesehariannya, orang yang menyandang down syndrome selain menghadapi permasalahan yang ada pada dalam dirinya, juga harus menghadapi permasalahan yang datang dari luar. Penerimaan masyarakat adalah hal yang menjadi sangat sensitif. Tidak semua masyarakat paham apa itu down syndrome sehingga memperlakukan mereka secara berbeda (diskriminasi). Sehingga dalam berbagai aspek kehidupan, seorang yang menyandang down syndrome kadang tidak selalu dapat ikut serta menjadi bagian. Kesulitan berinteraksi dengan orang lain terutama dialami oleh penyandang down syndrome anakanak. Anak penyandang down syndrome kerap dikucilkan di lingkungan bermainnya. Keterlambatan perkembangan yang dimilikinya membuat teman sebayanya 'enggan' untuk bermain dengannya. Mereka juga kerap mendapatkan perilaku diskriminasi karena perbedaan kemampuan yang dimilikinya. Sehubungan dengan permasalahan tersebut, pekerja sosial memiliki tanggung jawab profesi dalam pemberian pelayanan dan intervensi terhadap penyandang down syndrome tersebut. Intervensi pekerjaan sosial dalam hal ini bertujuan untuk mencapai keberfungsian sosial mereka.
\end{abstract}

Kata kunci: down syndrome, diskriminasi, interaksi sosial

\begin{abstract}
ABSTRAC
The number of people with Down syndrome in Indonesia is about 300 thousand more. Down syndrome is a genetic disorder that occurs in humans that cause those who suffer from it have both physical and psychological abnormalities. In everyday life, people who have Down syndrome in addition to facing the problems that exist in him, also must face the problems that come from outside. Public acceptance is very sensitive. Not all people understand what is Down syndrome so treat them differently (discrimination). So in many aspects of life, a person who bears Down syndrome sometimes can not always participate to be a part. The difficulty of interacting with others is mainly experienced by children with Down syndrome. Children with Down syndrome are often ostracized in their playing environment. Developmental delays have made his peers 'reluctant' to play with him. They also often get discriminatory behavior because of their different abilities. In relation to these problems, social workers have a professional responsibility in providing services and interventions to people with Down syndrome. Interventions of social work in this regard aim to achieve their social functioning.
\end{abstract}

Key words: Down syndrome, discrimination, social interaction 


\section{PENDAHULUAN}

Berdasarkan data Susenas tahun 2012 jumlah penyandang disabilitas di Indonesia mencapai $2,45 \%$ dari total penduduk, yaitu sekitar 6 juta orang (bps.go.id, diakses tanggal 29 Maret 2017). Penyandang disabilitas ada yang dapat diidentifikasikan berdasarkan ciri-ciri fisik yang dimiliki dan ada yang tidak. Salah satu contoh penyandang disabilitas yang dapat kita kenali secara fisik adalah penyandang down syndrome. Down syndrome dapat kita kenali berdasarkan ciriciri yaitu bentuk muka yang datar (seperti ras mongoloid), mata yang sedikit juling, mulut kecil, kepala yang kecil, leher yang pendek, serta tangan dan kaki yang tergolong pendek (Evans-Martin, 2009: 14).

Jumlah penyandang down syndrome terupdate di Indonesia, terutama di Jawa Barat sendiri tidak diketahui secara pasti berapa totalnya. Hal tersebut karena memang belum ada yang secara spesifik meneliti tentang jumlah penyandang down syndrome di Indonesia. Namun, berdasarkan data pada tahun 2010 (kompas.com, diakses pada 22 Maret 2017) jumlah penyandang down syndrome di seluruh dunia ada sekitar 8 juta jiwa dan 300.000 lebih diantaranya ada di Indonesia.

Down Syndome merupakan suatu kelainan genetik yang terjadi sebelum seseorang lahir yang menyebabkan penderitanya mengalami keterbelakangan perkembangan fisik dan mental. Normalnya seorang manusia memiliki 23 pasang kromosom dari ayah dan ibunya atau 46 kromosom, namun pada penyandang down syndrome mereka mengalami kelainan menjadi 47 kromosom.. Hingga saat ini belum diketahui secara pasti penyebab down syndrome.

Penyandang down syndrome sering kali menjadi pusat perhatian orang-orang di sekitarnya. Penampilan secara fisik yang khas, membuat orang-orang selalu melihat ke arahnya ketika sedang berada di tempat umum. Baik itu melihat dengan pandangan sinis atau merendahkan, maupun heran karena secara fisik mereka memiliki perawakan yang unik dan berbeda dari kebanyakan orang.

Kesulitan berinteraksi dengan orang lain terutama dialami oleh penyandang down syndrome anak-anak. Anak down syndrome akan lebih lambat belajar dibandingkan dengan yang lainnya. Anak down syndrome mengalami kesulitan dalam belajar berbicara dan menangkap sinyal kontak dari orang lain. Sehingga, pada tahap ini orang tua harus lebih ekstra untuk mengajari anaknya berinteraksi dengan orang lain.

Anak penyandang down syndrome kerap dikucilkan di lingkungan bermainnya. Keterlambatan perkembangan yang dimilikinya membuat teman sebayanya 'enggan' untuk bermain dengannya. Mereka juga kerap mendapatkan perilaku diskriminasi karena perbedaan kemampuan yang dimilikinya. Tindakan pengecualian yang dilakukan oleh lingkungan sosial terhadap penyandang down syndrome dapat dikatakan sebagai suatu bentuk diskriminasi. Perilaku diskriminasi dalam hal ini merupakan salah satu bentuk tindakan yang melanggar Hak Asasi Manusia (UU No 39 Tahun 1999 tentang HAM). Anak penyandang down syndrome berhak diperlakukan sama seperti anak-anak lain yang tidak menyandang down syndrome.

Penyandang disabilitas memiliki kesempatan yang sama dalam segala aspek kehidupan, tidak terkecuali penyandang down syndrome. Perlakuan diskriminasi yang diterima penyandang down syndrome di lingkungan sosialnya mengindikasikan bahwa mereka belum terpenuhi haknya untuk diterima di masyarakat dan hidup bermasyarakat. Pekerja sosial merupakan profesi perlolongan kemanusiaan yang memiliki tugas utama yaitu membantu individu, kelompok, dan/atau masyarakat untuk berfungsi secara sosial. Keberfungsian sosial meliputi kemampuan untuk memenuhi kebutuhan, kemampuan untuk memecahkan masalah, dan kemampuan untuk dapat melaksanakan peras sesuai dengan status sosialnya (Wibhawa, 2010). Sehingga isu diskriminasi yang dialami oleh penyandang down syndrome menjadi relevan dengan bidang profesi pekerjaan sosial.

Yayasan Suryakanti Bandung adalah yayasan sosial nonprofit yang bergerak di bidang pengembangan potensi anak. Suryakanti memiliki 3 unit pelayanan yaitu yayasan, klinik dan Sekolah Luar Biasa. SLB tersebut mengani anak-anak dengan autis, mental retardasi, down syndrome, cerebral palsy, dan learning disability. Suryakanti memiliki tenaga pendidik yang dibekali dengan pengetahuan dan keterampilan tentang perkembangan anak (child development). Anak down syndrome yang bersekolah, dengan anak down syndrome yang tidak bersekolah tentu akan memiliki perkembangan yang berbeda. Hal tersebut berpengaruh juga terhadap 


\begin{tabular}{|c|c|c|c|c|}
\hline Jurnal Penelitian \& PKM & Juli 2017 & Vol 4, No: 2 & Hal: $129-389$ & $\begin{array}{c}\text { ISSN } \\
2442-448 X(p), 2581-1126(e)\end{array}$ \\
\hline
\end{tabular}

kemampuannya untuk berinteraksi dengan lingkungan sosialnya.

\section{METODE}

\section{Pendekatan Penelitian}

Penelitian ini bermaksud menjelaskan bagaimana interaksi sosial anak penyandang down syndrome dengan lingkungan sosialnya. Adapun studi kasus dilakukan di SLB PUSPPA Suryakanti, Bandung. Metode yang akan dilaksanakan pada penelitian ini adalah metode penelitian deksriptif dengan pendekatan kualitatif. Pengertian kualitatif adalah:

"Penelitian kualitatif merupakan metodemetode untuk mengeksplorasi dan memahami makna yang oleh sejumlah individu atau sekelompok orang dianggap berasal dari masalah sosial atau kemanusiaan" (Cresswell, 2010:4)

Sesuai dengan maksud dan tujuan peneliti, yaitu untuk melihat gambaran dan mendeskripsikan bagaimana interaksi yang terjadi antara anak penyandang down syndrom dengan lingkungan sosialnya. Maka pendekatan kualitatif adalah pendekatan yang tepat untuk mendapatkan hasil yang dimaksud.

\section{Teknik Pengumpulan Data}

Penelitian ini menggunakan teknik pengumpulan data sesuai dengan pengumpulan data umum dalam penelitian kualitatif, yaitu:

\section{Pra lapangan}

Penelitian dilakukan dengan melakukan studi literatur seperti, buku, jurnal, situs internet, laporan media serta sumber ilmiah lainnya yang relevan dengan permasalahan penelitian yakni interksi sosial dengan lingkungan sosial.

\section{Lapangan}

Teknik di lapangan dapat dilakukan dengan 2 cara, yaitu:

\section{- Observasi}

Pengamatan terhadap suatu objek yang diteliti baik secara langsung maupun tidak langsung untuk memperoleh data yang harus dikumpulkan dalam penelitian. Observasi yang dilakukan menggunakan observasi langsung yaitu peneliti terjun ke lapangan terlibat dengan menggunakan panca indra dan observasi tidak langsung mengamati perilaku individu dari jauh. Observasi langsung yang dilakukan terkait dengan penelitian yaitu asesmen.

\section{- Wawancara Mendalam}

Wawancara mendalam (in-depth interview) menggunakan instrument pedoman wawancara dengan semi terstruktur. Dengan wawancara mendalam dapat menggali dan mendapatkan data yang kaya dari informan. Wawancara direkam dengan menggunakan alat perekam (digital record) untuk memudahkan peneliti mendapatkan seluruh rekaman jawaban dari informan.

\section{HASIL DAN PEMBAHASAN}

\section{Down Syndrome}

Down syndrome adalah suatu kondisi keterbelakangan perkembangan fisik dan mental anak yang diakibatkan adanya abnormalitas perkembangan kromosom. Kromosom ini terbentuk akibat kegagalan sepasang kromosom untuk saling memisahkan diri saat terjadi pembelahan. (dokterindonesiaonline.com, diakses pada 22 Maret 2017). Kromosom merupakan seratserat khusus yang terdapat didalam setiap sel didalam badan manusia dimana terdapat bahanbagan genetik yang menentukan sifat-sifat seseorang. Selain itu down syndrome disebabkan oleh hasil daripada penyimpangan kromosom semasa konsepsi. Ciri utama daripada bentuk ini adalah dari segi struktur muka dan satu atau ketidakmampuan fisik dan juga waktu hidup yang singkat.

Anak penyandang down syndrome memiliki resiko lebih tinggi akan masalah kesehatan dibandingkan dengan anak-anak normal. Beberapa masalah yang erat kaitannya dengan anak-anak ini adalah: kelainan jantung, kepekaan terhadap infeksi pada mata maupun kelainan pada bentuk otak.

Semua down syndrome mempunyai keterbelakangan yang berbeda skalanya, namun tidak tertutup kemungkinan akan timbulnya satu kekuatan atau kelebihan bakat pada setiap individu. Anak-anak down syndrome juga dapat belajar duduk, berjalan, berbicara, bermain dan melakukan kegiatan-kegiatan lainnya, namun tentu 


\begin{tabular}{|l|l|l|l|l|}
\hline Jurnal Penelitian \& PKM & Juli 2017 & Vol 4, No: 2 & Hal: $129-389$ & ISSN \\
\hline
\end{tabular}

lebih lambat daripada anak-anak yang bukan penyandang down syndrome.

\section{Interaksi Sosial}

Menurut Gillin dan Gillin (dalam Soekanto, 2012:55), interaksi sosial merupakan hubunganhubungan sosial yang dinamis yag menyangkut hubungan antara orang-orang perorangan, antara kelompok-kelompok manusia, maupun antara orang perorangan dengan kompok manusia. Dalam berinteraksi seseorang individu atau kelompok sosial sedang berusaha atau belajar untuk memahami tindakan sosial seorang individu ataupun kelompok sosial lain. Interaksi sosial akan berjalan dengan tertib dan teratur bila individu dalam masyarakat dapat bertindak sesuai dengan konteks sosialnya, yakni tindakan yang disesuaikan dengan situasi sosial saat itu, tidak bertentangan dengan norma-norma yang berlaku, serta individu bertindak sesuai dengan kedudukannya dalam masyarakat.

Secara umum interaksi sosial dapat diartikan sebagai hubungan yang terjadi antara individu dengan individu, individu dengan kelompok, kelompok dengan kelompok yang saling berhubungan, baik dalam berkomunikasi maupun melakukan tindakan sosial.

\section{Lingkungan Sosial}

Pengertian lingkungan sosial menurut Dalyono (2010:133) adalah :

"Lingkungan sosial ialah semua orang/manusia yang mempengaruhi kita. Pengaruh lingkungan sosial ada yang diterima secara langsung dan ada yang tidak langsung. Pengaruh langsung seperti dalam pergaluan sehari-hari, seperti keluarga, teman-teman, kawan sekolah dan sepekerjaan dan sebagainya".

Sedangkan menurut Purba (2002: 13-14) lingkungan sosial adalah wilayah yang merupakan tempat berlangsungnya macam-macam interaksi sosial antara berbagai kelompok beserta pranatanya dengan simbol dan nilai serta norma yang sudah mapan, serta terkait dengan lingkungan alam dan lingkungan binaan atau buatan (tata ruang).
Berdasarkan uraian di atas, lingkungan sosial dapat disimpulkan sebagai lingkungan yang terdiri dari makhluk sosial yang membentuk sistem pergaulan yang besar peranannya dalam membentuk kepribadian seseorang.

\section{Simpulan dan Saran}

Merujuk pada studi literatur yang dilakukan oleh peneliti, maka penelitian mengenai interaksi sosial anak down syndrome dapat dilakukan di lingkungan keluarga, sekolah dan tetangga atau masyarakat. Keterbatan yang dimiliki oleh penyandang down syndrome dalam hal perkembangan pola pikir, membuat dirinya terhambat dalam berinteraksi. Adapun informasi mengenai interaksi sosial akan mudah didapatkan dengan cara kita mengamati langsung informan di lingkungan yang dimaksudkan, selain dengan teknik wawancara mendalam yang dilakukan.

\section{DAFTAR PUSTAKA}

\section{Buku}

Creswell, John W. 2010. Research Design: Pendekatan Kualitatif, Kuantitatif, dan Mixed. Yogyakarta: Pustaka Pelajar.

Dalyono, M. 2001. Psikologi Pendidikan. Jakarta: PT. Rineka Cipta.

Evans-Martin, F. Fay. 2009. Down Syndrome (Genes and Disease). New York: Infobase Publishing.

Purba, Johny. 2002. Pengelolaan Lingkungan Sosial. Jakarta: Yayasan Obor Indonesia.

Raharjo, ST. 2015. Assessment untuk Praktik Pekerjaan Sosial dan Kesejahteraan Sosial. Bandung: Unpad Press 2015. Dasar Pengetahuan Pekerjaan Sosial. Bandung: Unpad Press. 2015. Keterampilan Pekerjaan Sosial: Dasar-dasar. Bandung, Unpad Press.

Soekanto, Soerjono. 2012. Sosiologi Suatu Pengantar Cetakan ke-44. Jakarta: PT Raja Grafindo Persada. 


\section{Sumber Elektronik}

UU No 39 Tahun 1999 Tentang Hak Asasi Manusia

(No Author). 2010. Penduduk Menurut Wilayah dan Tingkat Kesulitan Mengingat/Berkonsentrasi. http://sp2010.bps.go.id/index.php/site/tabel?ti $\mathrm{d}=280$ \&wid $=0$ [29/03/2017]

The Doctor Indonesia. 2016. Down Syndrome, Penanganan dan Permasalahannya. Melalui https://dokterindonesiaonline.com/2016/06/23 /down-syndrome-penanganan-danpermasalahannya/. [22/03/2017] 